\title{
Analisis Hasil belajar efeKtif Dari Penerapan SMART LEARNING
}

\author{
Rafi Hidayat ${ }^{1}$, Dedi Prasetya ${ }^{2}$ \\ Jurusan Teknik Informatika \\ STMIK IKMI \\ raf h998@yahoo.com ${ }^{1}$, Prasetya de@gmail.com ${ }^{2}$
}

\begin{abstract}
Smart city is an urban place where information technology and digital communication are used to increase knowledge and utilize technology, intellectual resources and real to improve the quality of life. One of the main areas of smart cities is intelligent learning and education, which is a new concept of technology-enhanced learning. Measuring the effectiveness of smart education depends on measuring the desired learning outcomes. This paper suggests the main key features that must be considered when developing learning analysis tools to measure and assess each subject's learning outcomes. And it shows the relationship between intelligent learning environment, learning outcomes and learning analysis.
\end{abstract}

Keywords-smart learning, learning outcomes

\section{Pendahuluan}

Smart City adalah kota cerdas perkotaan di mana teknologi digital tertanam di semua layanan dan fungsi. Konsep Smart City adalah label umum yang mungkin menyiratkan pada berbagai tata nama dan konteks. Ini masih terus berkembang dan mencakup beberapa bidang, bidang dan sektor. Beberapa penelitian mencoba dan masih mencoba untuk mendefinisikan kota pintar dan untuk menentukan karakteristik utama dan aspek untuk setiap kota untuk dipertimbangkan agar menjadi pintar. Frost dan Sullivan mengidentifikasi beberapa aspek kunci yang mendefinisikan Kota Pintar (Gambar 1: Konsep Kota Pintar): tata pemerintahan dan pendidikan yang cerdas, energi cerdas, pembangunan pintar, mobilitas cerdas, infrastruktur pintar, teknologi cerdas, perawatan kesehatan yang cerdas dan warga negara yang cerdas [1]. Sementara Institute of Electrical and Electronics Engineers (IEEE) mendefinisikan Smart City sebagai kota yang menyatukan teknologi, pemerintah dan masyarakat untuk mengaktifkan karakteristik berikut: kota pintar, ekonomi pintar, mobilitas cerdas, lingkungan yang cerdas, orang pintar, pintar hidup, pemerintahan yang cerdas.

Salah satu aspek utama untuk kota menjadi pintar adalah mengembangkan pendidikan pintar dan lingkungan belajar yang cerdas. Smart Learning Environment (SLE) adalah lingkungan yang meningkatkan teknologi pembelajaran yang mengintegrasikan kriteria dan fungsi sistem pembelajaran cerdas dan pembelajaran sadar konteks di mana-mana. Sedangkan Smart Education adalah sistem pendidikan yang memungkinkan siswa untuk belajar dengan menggunakan teknologi terbaru dan memungkinkan mereka untuk belajar kapan saja dan di mana saja melalui teknologi yang ditawarkan di Lingkungan Belajar Cerdas mereka [2]. Menurut Tikhomirov, Dneprovskaya dan Yankovskaya, Pendidikan Cerdas memiliki tiga dimensi utama: hasil pendidikan dan pembelajaran, ICT dan teknologi cerdas yang ditawarkan dan dimensi organisasi [3] Dalam makalah ini, kami menekankan pada pentingnya pengukuran yang efektif untuk hasil pembelajaran sebagai aspek utama dalam lingkungan belajar yang cerdas. Tujuan dari makalah ini adalah untuk menemukan cara yang lebih efektif dan tepat untuk mengukur dan menilai hasil pembelajaran. Pada bagian berikut, makalah ini menunjukkan hubungan antara lingkungan belajar cerdas, hasil belajar dan analisis pembelajaran. Kemudian, ini 
menunjukkan fitur utama utama untuk dimasukkan dalam setiap alat analisis pembelajaran yang dikembangkan untuk digunakan dalam menilai dan mengukur hasil pembelajaran. Akhirnya, makalah ini menyoroti beberapa tantangan yang mungkin dihadapi untuk mengembangkan alat LA semacam itu dan menyarankan pekerjaan di masa depan.

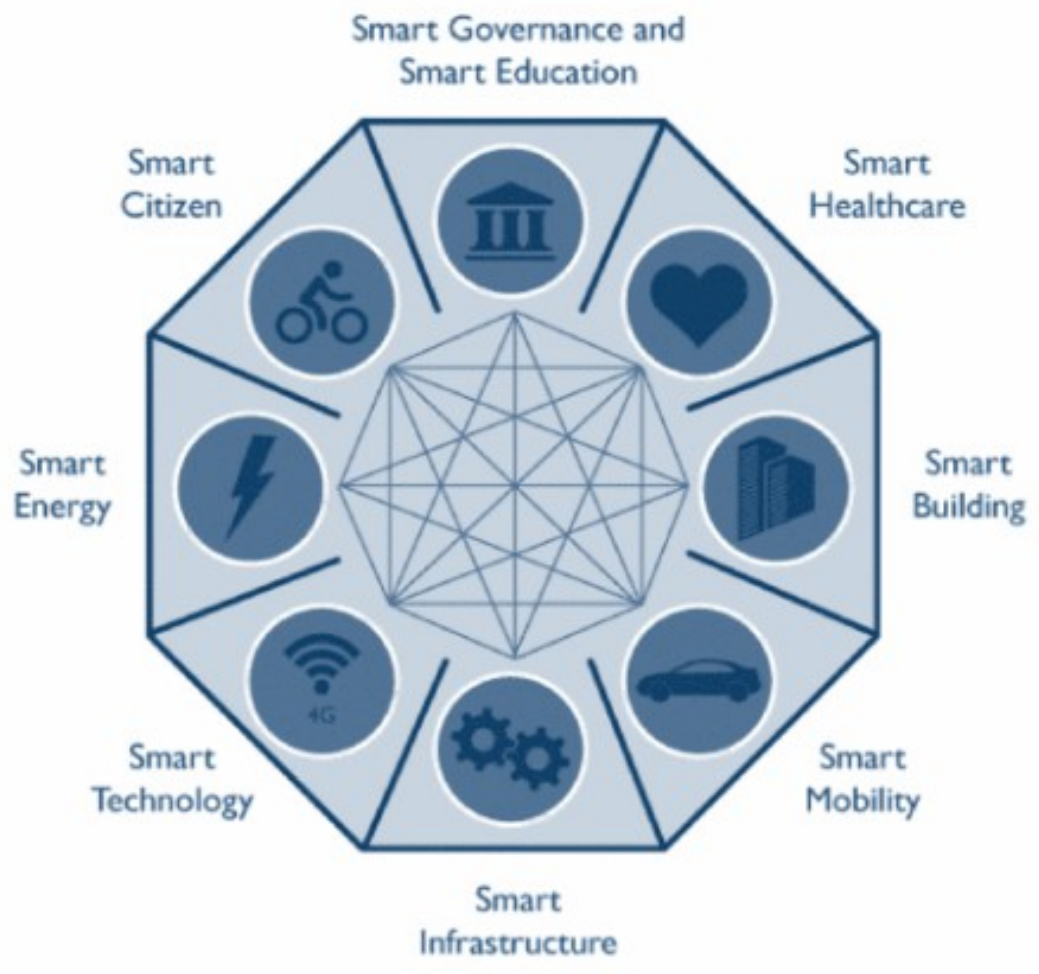

Gambar 1 : Konsep Smart City

\section{LANDASAN TEORI}

Banyak upaya penelitian mencoba mendefinisikan lingkungan belajar cerdas (SLE) dan untuk mengidentifikasi karakteristik utama yang membentuk lingkungan semacam itu. Huang dan Chang mendefinisikan SLE sebagai ruang belajar yang terbuka, cerdas dan terintegrasi berdasarkan teori pembelajaran konstruktivis, teori pembelajaran terpadu dan metode pendidikan modern yang terdiri dari perangkat, alat, teknik, media, sumber pengajaran, dan komunitas guru dan pelajar yang terkait. [4] Koper mendefinisikan SLE sebagai lingkungan fisik yang diperkaya dengan perangkat digital, konteks sadar dan adaptif, untuk mempromosikan pembelajaran yang lebih baik dan lebih cepat [5]. Lingkungan belajar cerdas juga didefinisikan sebagai lingkungan pembelajaran yang didukung teknologi yang membuat adaptasi dan memberikan dukungan yang sesuai (misalnya, panduan, umpan balik, petunjuk atau alat) di tempat yang tepat dan pada waktu yang tepat berdasarkan kebutuhan pembelajar individu, yang mungkin ditentukan melalui analisis perilaku belajar mereka, kinerja dan konteks online dan dunia nyata di mana mereka berada [6]

Lingkungan belajar yang cerdas tidak hanya memungkinkan peserta didik untuk mengakses sumber daya digital dan berinteraksi dengan sistem pembelajaran di mana saja dan kapan saja, tetapi juga aktif memberikan bimbingan pembelajaran yang diperlukan, petunjuk, alat yang mendukung atau saran pembelajaran kepada mereka di tempat yang tepat, di sebelah kanan. waktu dan dalam bentuk yang benar. Pada dasarnya, sistem pembelajaran cerdas dapat dianggap sebagai sistem pembelajaran yang disempurnakan dengan teknologi yang mampu menasihati para pembelajar untuk belajar di dunia nyata dengan akses ke sumber daya dunia digital. 


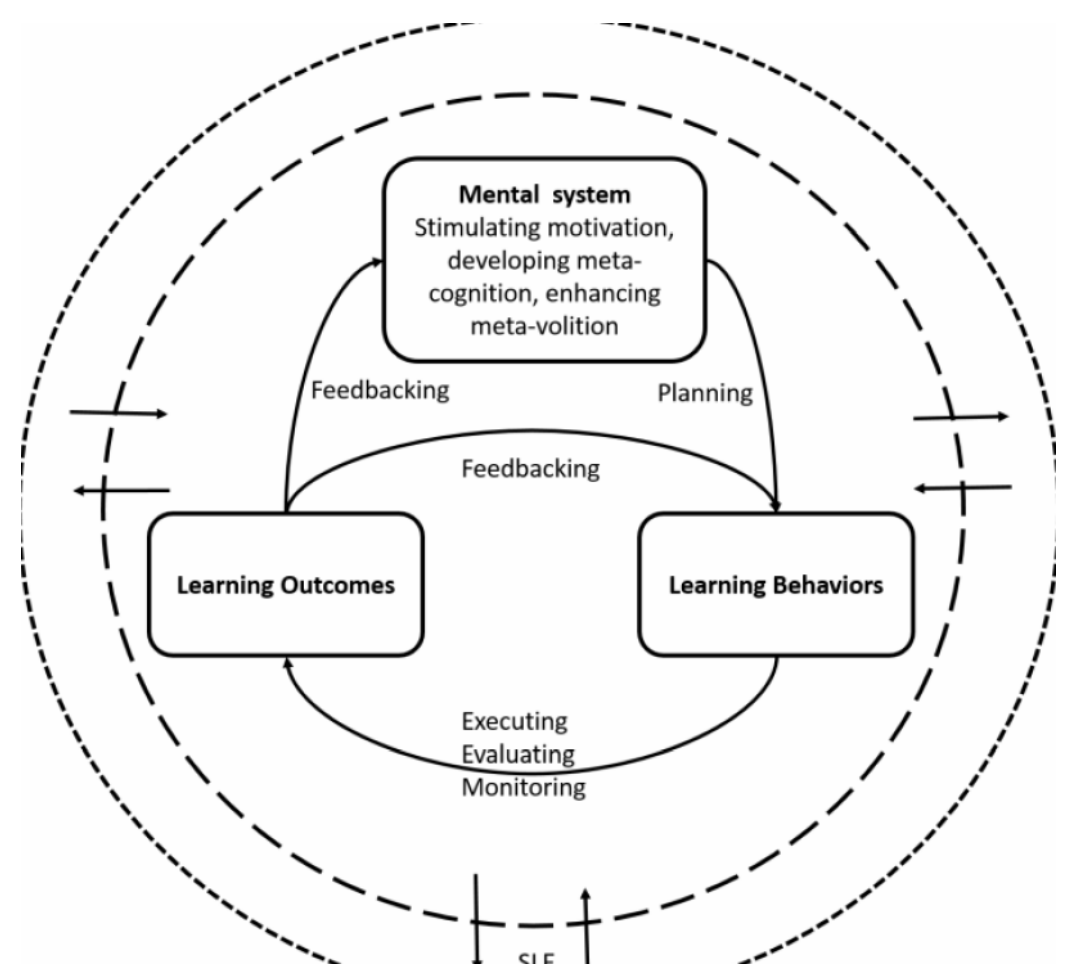

Gambar 2 : Smart Learning cycle

Siklus belajar cerdas yang efektif terdiri dari tiga faktor: sistem mental, perilaku belajar dan hasil belajar. (Gambar 2: Siklus Belajar Cerdas [4].

Komponen kunci dari sistem mental adalah motivasi untuk belajar, meta-kognisi dan kemauan meta. Persiapan mental pembelajaran cerdas yang efektif termasuk membangkitkan sistem mental peserta didik, mengembangkan meta-kognisi dan meningkatkan meta-kemauan. Kondisi untuk pembelajaran cerdas yang efektif adalah bahwa peserta didik memiliki motivasi untuk menerima tugas belajar dan ingin berpartisipasi dalam kegiatan pembelajaran. Berbagai pemangku kepentingan dalam SLE seperti instruktur, peserta didik dan orang tua memiliki banyak cara untuk berkomunikasi satu sama lain dalam rangka membangun pemahaman yang tepat tentang hubungan antara hasil belajar dan perilaku belajar.

Perilaku belajar adalah interaksi dua arah antara peserta didik dan lingkungan belajar, tujuan dari perilaku ini adalah untuk menyebabkan perubahan yang diinginkan dalam apa yang pelajar ketahui dan apa yang dapat mereka lakukan. Perilaku pembelajaran dalam SLE ini dapat diringkas sebagai perilaku pengambilan informasi, pemrosesan informasi, pelepasan informasi dan komunikasi interpersonal.

Hasil Pembelajaran adalah pernyataan formal tentang apa yang diharapkan siswa pelajari dalam suatu kursus. Pernyataan hasil belajar yang diharapkan mengacu pada pengetahuan khusus, keterampilan praktis, bidang pengembangan profesional, sikap, keterampilan berpikir tingkat tinggi, dll. Yang anggota fakultas mengharapkan siswa untuk mengembangkan, belajar atau menguasai selama kursus. Hasil pembelajaran harus SMART: Spesifik dan sederhana - Terukur - Tercapai dan dapat dicapai - Realistis dan relevan - Terikat waktu dan tepat sasaran. Hasil pembelajaran tersebut harus dihasilkan dari interaksi yang berbeda dalam SLE [7]

\section{ANALISISI TEKNOLOGI PADA LINGKUNGAN SMART LEARNING}

Lingkungan belajar yang cerdas mampu merekam setiap detail dari perilaku belajar siswa. Ini juga memberikan kesempatan yang baik untuk berbagai pemangku kepentingan seperti instruktur, peserta didik, lembaga pendidikan dan peneliti untuk memperoleh informasi berharga dan penting 
melalui analisis perilaku ini. SLE melibatkan kesadaran konteks. Dimana konteks dapat mencakup pengetahuan awal pengguna, gaya belajar, kecepatan belajar, kegiatan saat ini, tujuan (hasil), waktu belajar yang tersedia, lokasi dan minat [8]. Semua informasi yang dikumpulkan tentang perilaku belajar siswa dan interaksinya dengan konteks yang berbeda perlu dianalisis agar bermanfaat. Kebutuhan ekstraksi dan analisis untuk data turunan menarik perhatian masyarakat teknologi dan cerdas. Oleh karena itu, berbagai teknologi analitik mulai bergabung dengan proses pembelajaran karena melibatkan teknik dan alat yang digunakan untuk memproduksi dan mengomunikasikan 'kecerdasan yang dapat ditindaklanjuti' dari kumpulan data besar yang mengarah ke pengambilan keputusan berdasarkan data [9]. Teknologi analisis dapat menggabungkan aspirasi pribadi siswa dalam menilai nilai peluang pembelajaran yang ditentukan [10].

Belajar analytics mendukung lingkungan belajar cerdas siswa. Karena membantu dalam memantau perilaku siswa tepat waktu dan memanfaatkan informasi jaringan untuk diskusi dan aktivitas interaksi yang lebih efektif dan cerdas. Pada tahun 2006 Retalis mempertimbangkan analisis pembelajaran dan analisis interaksi sebagai cara yang menjanjikan untuk lebih memahami perilaku pembelajar [11] Perilaku pembelajar yang disediakan dalam sistem manajemen pembelajaran yang berbeda adalah beberapa alat pintar yang memberikan umpan balik instan tentang perilaku belajar dan membantu peserta didik mengidentifikasi nilai studi mereka. Mereka juga membantu mengenali kesenjangan antara pengetahuan, keterampilan, dan hasil pembelajaran yang diproyeksikan dengan mengukur kemajuan siswa dalam tugas dan kegiatan terkait. Perilaku pembelajar dapat melacak dan mencatat proses pembelajaran dan hasil pembelajaran dan memberikan pengguna dengan konten pembelajaran yang tepat untuk mengisi kesenjangan tersebut dengan mempertimbangkan konteks pengguna. Mempelajari alat analitik yang disediakan di platform LMS dan khususnya dalam fokus Moodle pada penilaian kinerja siswa dan kemajuan akademik seperti partisipasi siswa, penyelesaian aktivitas, ikhtisar kursus, bilah kemajuan, dan analisis keterlibatan. Mendefinisikan hasil kursus di LMS seperti Moodle sudah tersedia tetapi dengan banyak keterbatasan mengenai analitik, alat dan teknik yang dibutuhkan untuk menilai hasil pembelajaran tersebut dan untuk mengukur pencapaian siswa.

Ada kebutuhan untuk alat analisis yang dapat mengukur kinerja siswa dalam kegiatan LMS yang berbeda dan menghubungkannya dengan hasil pembelajaran yang sesuai, dengan kata lain untuk mengukur pengaruhnya terhadap hasil belajar siswa. Alat-alat tersebut akan membantu dalam mengevaluasi tingkat pencapaian hasil pembelajaran yang akan membantu dalam membuat keputusan tentang apa yang akan terjadi selanjutnya. Untuk mengembangkan alat analitis yang efektif yang memfasilitasi pengukuran hasil pembelajaran, memprediksi kinerja dan menilai pengambilan keputusan, makalah ini mengusulkan beberapa fitur utama untuk dipertimbangkan dalam tahap desain dan implementasi.

\section{FItUR PENGUKURAN HASIL BELAJAR}

Fitur utama yang kami usulkan bertujuan untuk membantu mengembangkan alat analisis pembelajaran yang mampu meramalkan keberhasilan siswa terhadap hasil kursus menggunakan kegiatan LMS yang berbeda dan berfungsi sebagai sistem peringatan dini.

\section{A. Memetakan Kegiatan LMS Terhadap Hasil Belajar yang Berbeda}

Setiap LMS seperti Moodle menangkap dan menyimpan sejumlah besar aktivitas pengguna yang canggih dan data interaksi. Berbagai jenis data dapat dianggap sebagai kegiatan siswa dan dapat dilibatkan dalam mengukur hasil kursus. Jenis kegiatan tersebut dapat dihasilkan oleh LMS itu sendiri sebagai hasil dari interaksi pengguna seperti jenis sumber daya yang diakses, frekuensi login, penilaian terbuka dan selesai dan keterlibatan situs lainnya atau dapat dihasilkan oleh instruktur dan disimpan dalam LMS seperti kuis, penilaian, dan tugas. Kegiatan Belajar yang berdampak tinggi itu terkait secara signifikan dengan semua ukuran hasil pembelajaran. Sangat penting untuk mengidentifikasi kegiatan- 
kegiatan tersebut dan memetakannya ke hasil pembelajaran terkait dengan cara yang membantu dalam menentukan secara dinamis tingkat pencapaian hasil pembelajaran. Tingkat pencapaian hasil belajar akan tergantung pada penyelesaian kegiatan terkait selama jangka waktu tertentu. Sebagai contoh, jika pelajar menyelesaikan sejumlah tertentu dari kegiatan terkait dalam durasi tertentu maka ia menguasai hasil belajar yang terkait.

\section{B. Perancangan Peta Kursus}

Dalam rangka meningkatkan tingkat kecerdasan alat analitis untuk dapat membuat keputusan dan rekomendasi pada penilaian hasil pembelajaran, infrastruktur yang efektif harus dibangun dengan cara menganalisis akar dari setiap kegiatan dan urutan hasil pembelajaran yang berbeda di tentu saja. Itulah sebabnya, peta kursus yang dinamis harus dikembangkan secara efektif yang menarik banyak jenis informasi tentang subjek dan menyajikan semuanya dalam satu dokumen atau peta interaktif "tuan".

Peta kursus adalah representasi tentang bagaimana instruktur bermaksud untuk mendekati dan menilai setiap hasil belajar siswa yang diidentifikasi menggunakan kegiatan LMS. Ini merupakan hasil pembelajaran dalam urutan kronologis yang harus diikuti selama semester. Ini membantu untuk menyelaraskan unsur-unsur kursus yang merupakan topik, isi kursus, hasil belajar, kegiatan belajar dan penilaian dan minggu semester bersama-sama. Pemetaan kursus interaktif seharusnya tidak hanya menunjukkan hasil pembelajaran yang diurutkan dengan kegiatan LMS yang terkait tetapi juga harus menempatkan kegiatan tersebut pada skala pencapaian hasil pembelajaran. Dengan kata lain, jika siswa menyelesaikan kegiatan dengan nilai tertentu yang berarti bagian dari skala tercapai atau ditutupi. Bobot harus diberikan untuk masing-masing kegiatan yang dipetakan untuk memudahkan menganalisisnya nanti.

\section{Analisis Kualitatif}

Sebagian besar analitik terkait LMS menyediakan jejak kegiatan peserta didik pada sistem dan data ini kemudian digunakan untuk membantu manajemen dan efektivitas pengajaran dan pembelajaran institusional. Dawson menambahkan bahwa analisis data ini dapat digunakan untuk meningkatkan pengalaman belajar siswa [12]. Itu berarti alat analisis tidak boleh hanya menerapkan analisis kuantitatif, tetapi juga kualitatif, atau setidaknya interpretasi kualitatif temuan. Analisis dan interpretasi kualitatif harus memasukkan penilaian nilai pada penggunaan lingkungan oleh para pelajar. Misalnya, tidak hanya menghitung siapa yang menggunakan lingkungan untuk apa, tetapi juga menilai apa yang mungkin baik dan apa yang mungkin menjadi pengalaman buruk, dan menawarkan saran untuk bergerak pada kontinum dari satu ke yang lain.

\section{Identifikasi Tolok Ukur}

Ada kebutuhan untuk mengidentifikasi tolok ukur bagi hasil pembelajaran untuk mengidentifikasi kesenjangan, membangun kasus bisnis, dan mengambil tindakan. Pentingnya pembandingan adalah untuk meningkatkan efektivitas proses pendidikan. Norris, Baer dan Offerman menekankan perlunya pembandingan baik di dalam, dan di seluruh institusi, dengan penekanan khusus pada pengembangan praktik yang membuat mereka efektif: "hasil analisis yang paling penting, analitik tindakan" sangat bermanfaat hanya dapat terjadi di perusahaan dan lingkungan yang benar-benar berkomitmen untuk mengukur dan meningkatkan aspek kunci dari produktivitas, inovasi, dan kinerja [13].

\section{E. Keterbukaan}

"Keterbukaan" dan "analisis pembelajaran" adalah dua tren yang berkembang dalam teknologi pendidikan. Learning Analytics memberikan bukti empiris tentang perubahan apa yang diperlukan sementara keterbukaan memberikan izin untuk melakukan perubahan, adaptasi, dan peningkatan pada 
sumber belajar. Keterbukaan proses, algoritma, dan teknologi memungkinkan para peneliti untuk mengembangkan alat dan metode mereka sendiri untuk diintegrasikan dengan platform apa pun. Platform analisis pembelajaran harus menjadi arsitektur terbuka dengan standar untuk menambahkan plugin baru. Analisis pembelajaran terbuka memastikan peningkatan kualitas berkelanjutan. Sebagian besar analisis pembelajaran terkait LMS berorientasi pada peneliti dan tutor. Tujuan utama dari teknik LA adalah adaptasi, pemantauan, dan prediksi. Oleh karena itu, ada kebutuhan untuk Open Learning Analytics yang mewakili perpotongan antara analisis pembelajaran dan teknologi pembelajaran terbuka seperti menggunakan standar terbuka, API, dan perangkat lunak sumber terbuka.

\section{Tantangan dan PekerJaan Selanjutnya}

Salah satu tantangan yang mungkin terkait dengan fitur-fitur utama adalah memastikan bahwa rencana kursus dirancang dengan baik dan bahwa keselarasan antara hasil pembelajaran yang dianut dan kegiatan LMS yang berbeda adalah pencocokan yang tepat. Mengkonfirmasi bahwa berbagai aktivitas LMS dapat diandalkan, cukup dan memadai untuk mengukur hasil yang diadopsi secara akurat dan tepat. Tantangan lain dapat ditingkatkan ketika kita berhadapan dengan sejumlah besar data yang mengidentifikasi data yang diperlukan yang tepat untuk dianalisis. Data yang diekstraksi dari sistem LMS pada dasarnya tidak cerdas. Hitungan jumlah, pola akses, jumlah sumber daya yang diakses dan jenis sumber daya yang diakses tidak benar-benar menjelaskan apa pun oleh mereka sendiri. Intelijen di sini datang dalam interpretasi data dengan keterampilan analitis yang efektif.

Salah satu pekerjaan yang menjanjikan di masa depan dapat dilakukan dengan berfokus pada keefektifan menggabungkan metode kuantitatif dan kualitatif analisis untuk mencapai luas dan kedalaman analisis data dan interpretasi. Analisis kuantitatif fokus pada tingkat dasar penilaian dan pelaporan pada kegiatan pembelajar sementara alat dan pendekatan kualitatif menunjukkan seberapa dalam pemeriksaan konten dapat mengungkapkan jenis kontribusi yang dibuat, serta pengetahuan, informasi, alat, dan pengalaman yang mempromosikan pembelajaran dalam proses pendidikan.

\section{KESIMPULAN}

Perilaku pembelajar memiliki potensi dalam konteks menilai hasil pembelajaran yang merupakan salah satu dimensi utama dari pendidikan berorientasi tujuan cerdas. Dalam makalah ini kami merekomendasikan beberapa fitur utama untuk dipertimbangkan dalam merancang alat analisis pembelajaran yang efektif yang digunakan untuk mengukur dan menilai hasil pembelajaran mata pelajaran dan memprediksi keberhasilan siswa. Fitur-fitur utama ini meningkatkan pengembangan alat analisis pembelajaran yang dapat disesuaikan berdasarkan kebutuhan kursus, kegiatan dan persyaratan, dapat diadaptasi dalam platform LMS mana pun dan efektif dalam membuat keputusan dan rekomendasi berdasarkan analisis kuantitatif dan kualitatif.

\section{REFERENSI}

[1] S. Singh, "Smart Cities--A 1.5 Trillion Market Opportunity," Forbes. Retrieved, vol. 4, 2014.

[2] S. Jang, "Study on service models of digital textbooks in cloud computing environment for SMART education," Int. J. u-and e-Service, Sci. Technol., vol. 7, no. 1, pp. 73-82, 2014.

[3] V. Tikhomirov, N. Dneprovskaya, and E. Yankovskaya, "Three Dimensions of Smart Education," in Smart Education and Smart e-Learning, Springer, 2015, pp. 47-56.

[4] X. Liu, R. Huang, and T.-W. Chang, "Design of Theoretical Model for Smart Learning," in Stateof-theArt and Future Directions of Smart Learning, Springer, 2016, pp. 77-86.

[5] R. Koper, "Conditions for effective smart learning environments," Smart Learn. Environ., vol. 1, no. 1, pp. 1-17, 2014. 
[6] G.-J. Hwang, T.-C. Yang, C.-C. Tsai, and S. J. H. Yang, "A context-aware ubiquitous learning environment for conducting complex science experiments," Comput. Educ., vol. 53, no. 2, pp. 402-413, 2009.

[7] K. B. Lawlor, "Smart goals: How the application of smart goals can contribute to achievement of student learning outcomes," Dev. Bus. Simul. Exp. Learn., vol. 39, 2012.

[8] D. Boulanger, J. Seanosky, V. Kumar, K. Panneerselvam, T. S. Somasundaram, and others, "Smart Learning Analytics," in Emerging Issues in Smart Learning, Springer, 2015, pp. 289-296.

[9] A. van Barneveld, K. E. Arnold, and J. P. Campbell, "Analytics in higher education: Establishing a common language,” Educ. Learn. Initiat., vol. 1, pp. 1-11, 2012.

[10] G.-J. Hwang, "Definition, framework and research issues of smart learning environments-a contextaware ubiquitous learning perspective," Smart Learn. Environ., vol. 1, no. 1, pp. 1-14, 2014.

[11] S. Retalis, A. Papasalouros, Y. Psaromiligkos, S. Siscos, and T. Kargidis, "Towards Networked Learning Analytics--A concept and a tool," in Proceedings of the fifth international conference on networked learning, 2006.

[12] S. Dawson, L. Heathcote, and G. Poole, "Harnessing ICT potential: The adoption and analysis of ICT systems for enhancing the student learning experience," Int. J. Educ. Manag., vol. 24, no. 2, pp. $116-128,2010$.

[13] D. Norris, L. Baer, and M. Offerman, "A national agenda for action analytics," in National Symposium on Action Analytics, 2009, pp. 21-23. 